\title{
Wine Cooler
}

National Cancer Institute

\section{Source}

National Cancer Institute. Wine Cooler. NCI Thesaurus. Code C66823.

An alcoholic beverage made from wine and fruit juice, often in combination with a carbonated beverage and sugar. 